References

HEITYELD K.-H. (1964): Hydro- und baugeologische Untersuchungen über die Durchlässigkeit des Untergrundes an Talsperren des Sauerlandes (Hydrogeological and engineering geological investigations into permeability of the underground of dams in the Sauerland, F. R. Germany). Geol. Mitt. 5, 1-210.

INDEPENDENT PANEL TO REVIEW CALSE OF TETON DA.H FAILURE (1976): Failure of Teton Dam. Idaho Falls.
LLCFON M. (1933): Barrages et (jéologie. Lawanne. Rouge \& Cie.

\section{S. DEPARTMFNT OF THE INTERIOR TETON DAN FAILLRE REVIEW GROLP (1977): Failure of Teton Dam. A report} of Findings, A pril 1977.

REDLICH K. A. - TERZAGHI K. - KAMPE R. (1929): Ingenieurgeologie (Engineering Geology). Wien \& Berlin, Springer.

\title{
Closing Address
}

\section{Allocution de clòture}

Ladies and Gentlemen,

At the end of an IAEG event, of a symposium or a congress, it has come to be the task and the privilege of the Secretary in the past years to make a few closing remarks. I must admit, this is not at all difficult here and today, because the theme of this symposium is of eminent importance for enginering geology, for the population, and for the safe and adequate utilization of our earth. Engineering geology applied to hydrotechnical and dam construction is equally important for further development and structural improvements and thus for the well-being and prosperity of people and it is also one of the conditions required to prevent or mitigate the effects of many natural disasters.

No wonder therefore that in the past days scientists with a worldwide reputation have presented the state of the art in eight sessions, and that so many experts have joined together here to present, discuss and familiarize themselves with the new experiences made in these special geotechnical fields.

In fact it is an essential aim of our association to look out again and again for new and better methods in our discipline and to communicate them to all who are interested. But it is also necessary and sensible to reveal faults and faulty conclusions; firstly, in order to alert fellow scientists - considering our responsibility vis-à-vis the population - and secondly, in order to review the course of our investigations and to check whether we are on the right way or not. We are all responsible in this sense. Some have shown courage and responsibility in these days. But I want to alert still more colleagues, I want to call upon each and everyone whose experience enables him to help avoid damage, to publish his ideas in our Bulletin. Thus we fulfil our professional duty and act honestly and decently.

In retrospect I feel that we have made decent progress in the last days on our way towards a rational knowledge of the underground and its properties and towards the art of using them skillfully, so that we may still better succeed in controlling water and water courses and in averting dangers inherent in them, for the benefit and welfare of Man.

It is the achievement of the National Group of the USSR who orga nized this symposium to have essentially contributed to the solution of these problems, and they deserve the gratitude of the engineering geology community and of the IAEG. I believe though. that all those present feel a much greater and deeper gratitude. Our hosts. the ladies and gentlemen of the Academy of Sciences of the Georgian SSR, have arranged everything in such an agreeable and pleasant manner that everybody's feelings cannot be other than pleasure, harmony and satisfaction.

It is one of the main aims of our organisation to arrange for our members opportunities to join together in conferences and ex change experiences, discuss and advance the state of our art and to foster human contacts; for all this we have found optimum conditions and a very suitable place here, and not just by chance. For milleniums this region has been one of the places on our earth where men and entire people met on their migrations into various directions. This historical heritage has set the characters of the people living here. Besides their cautiousness and critical vigilance due to experience, they have developed a very particular disposition for hospitality and good spirits. They are hospitable towards each other and towards the visitor who has stood the test of their scrutinizing eye. I think that I may well speak for everybody here if I extend our warm thanks to the organisers for the delightiul days and for the efforts and sacrifices of the many who prepared them. As I am unable to enumerate all those who were involved in some way, from government agencies to the translators, I just mention two for all: Prof. Buachidze and Prof. Haindraya.

There are two things that will make this symposium unforgettable: the scientific results will be documented in the more than 70 articles to be published in No. 20 of our Bulletin, and the impressions of the meeting of so many people in sincerity and harmony in the setting of a wonderful landscape will long be inscribed in the hearts.

We part highly impressed, enriched with the events of these days, with warm feelings of gratitude, and we wish each other "goodbye and see you again". 